\section{Grundig om medisinske TV-serier}

Joseph Turow

Playing doctor

Television, storytelling, and medical power. 451 s, ill. Ann Arbor, MI: University of Michigan Press, 2010. Pris USD 35

ISBN 978-0-472-03427-7

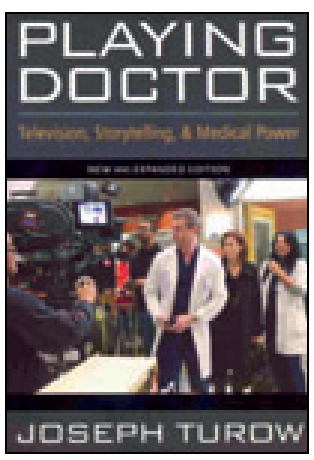

Dette er en fagbok, skrevet av en amerikansk professor i medievitenskap. Den omhandler hvordan legen og faget medisin fremstilles i massemedia, vesentlig med vekt på amerikanske fjernsynsserier. Boken bygger på intervjuer med

fagfolk som arbeider i produksjonen av amerikanske medisinske serier, som ER, House og Scrubs. Den dekker vel 130 forskjellige medisinske TV-serier fra 1950-årene til i dag.

De fleste av oss kjenner medisinske såpeoperaer og TV-serier. Forfatteren viser hvordan sjangeren er blitt både mer profesjonell TV-underholdning og mer realistisk i de siste årene. Hovedskillet kom med $E R$ i 1994. Med sin intense flimring og frenetiske skifte av scener satte den ny standard for all fjernsynsunderholdning. Den brøt også grenser med sitt kameranære fokus på lidelse, død og store mengder organisk gørr. Først og fremst var $E R$ imidlertid en nyskapning i personportretteringen. Legene i serien, både kvinner og menn, hadde et rikt spekter av personlige uvaner og alle seksuelle legninger. Alle etnisiteter var representert. I det senere er pasientene blitt mindre sentrale på skjermen, og bildet er blitt mer og mer sentrert om legen. I House er tendensen ført til det ekstreme. Hele serien dreier rundt den Sherlock Holmesaktige eksentrikeren dr. House.

Forfatteren viser også hvordan samme serier systematisk lar være å ta opp økonomiske og organisasjonsmessige realiteter, som misforholdet mellom høyteknologiske løsninger og tilgjengelige resurser. Seriene tegner i det alt overveiende et bilde av et helsevesen med ubegrensede ressurser.

Boken utkom første gang i 1989. Den er oppdatert og utvidet, men virker likevel betydelig eldre. Illustrasjonene er svarthvitt-fotografier, og de er samlet midt i, uten sammenheng med den løpende teksten. Selv «nyere», veletablerte serier som House og Scrubs er underrepresentert i forhold til ER, Chicago Hope og $M^{*} A * S^{*} H$ ! Dagens sosiale medier benyttes ikke som kilde. Teksten er likevektig og litt tørr. Forfatteren presenterer sosiopolitiske argumenter, men lar dem ikke stå med egen tyngde.

Denne boken kan være solid bakgrunns- litteratur for den som er interessert i medisinske TV-serier. Den kan også egne seg som fritidslektyre (erstatning for påskekrim?) for dem av oss som liker en grundig fremstilling av et spennende stoff.

\section{Anders Bærheim}

Institutt for samfunnsmedisinske fag Universitetet i Bergen

\section{Leger på filmduken}

\section{Brian Glasser}

\section{Medicinema}

Doctors in films. 148 s. Oxon: Radcliffe, 2010. Pris GBP 20

ISBN 978-1-84619-157-2

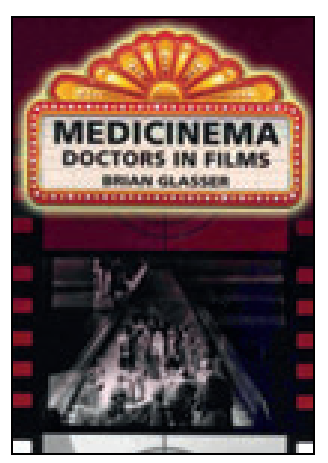

Ideen er utmerket: å skrive en bok om hvordan leger blir portrettert gjennom filmhistorien. Leger er en av de profesjonene som hyppigst er blitt vist frem på lerretene de siste 100 årene. Av forståelige grunner finnes langt færre levende bilder om rørleggere eller meteorologer. Leger er tett på livene, fordi de er tett på smerten og døden. Filmhistorisk var legene der før cowboyer, skurker og geistlige. Den åpenbare målgruppen er således leger selv, da man jo liker å lese om nettopp seg selv. Forfatteren, som selv er sosiolog, tenker også at filminteresserte bør lese dette. Men forfatteren mislykkes. Og det solid.

De tette båndene mellom film og medisin kan komme til uttrykk som pedagogisk motiverte tekster som anvender filmer for å illustrere kliniske tilstander. Boken Cinemeducation er et eksempel på dette (1). Og medisinstudenter legitimerer gjerne sitt konsum av TV-serien House med at det er pensumrelevant. Det finnes egne bøker hvor psykiatere guides til å finne filmer som illustrerer de fleste av de tilstandene som er beskrevet i psykiatriens diagnoseoversikter $(2,3)$. Fortrinnsvis i amerikanske sammenhenger kan man støte på begrepet film therapy, som viser til at filmer blir brukt som redskaper i psykoedukative gruppesamtaler med pasienter.

\section{Fragmentariske vaskesedler}

Brian Glassers filmblikk går altså en annen vei. Det er ikke filmen som pedagogisk redskap han vier seg til, men filmen som en tekstanalytisk kilde til å si noe om oppfatningen av legers virksomhet. Filmen som medium beveger seg i spenningsfeltet mellom kunst og kommersiell underhold- ning, og slik sett er den en høyst relevant kilde for å fange opp kulturelle blikk på menneskelige fenomener, som medisinske praksiser.

Etter innholdsfortegnelsen er jeg klar: Hippokrates som horror, dvs. leger i skrekkfilmer; leger i krig; medisinske melodramaer osv. Prosjektet går raskt i oppløsning. Det finnes egentlig ikke noe prosjekt. Glasser følger ikke noen klare idémessige eller analytiske spor. Han har ingen samlende teser og ingen klar metode. Et stort antall filmer nevnes, men de blir sjeldent undersøkt, bare omtalt på et begrenset antall linjer. Boken er mer en stabel av vaskesedler, et stykke filmografisk arbeid, enn fortolkninger. Filmtitler fra forskjellige epoker blir stablet sammen, og jeg tenker: Hva så? En epoketilnærming kunne eksempelvis vært interessant; dvs. hvorvidt eller hvordan filmen som populærkulturell utkikkspost forteller om et endret syn på legeprofesjonen. Mellomkrigslegen, 50tallslegen, 68er-legen, Reagan-legen osv. Men nei.

$\AA ̊$ si at denne boken er overfladisk, er nesten en kompliment. Den er så fragmentarisk at hele flater ikke kan skues. Det er nærmest uunngåelig å få fantasier om hvordan boken er blitt til. Forfatteren har hatt en hyggelig forelesningsserie gjennom et semester eller to, på et innføringsnivå, med filmklipp og kommentarer og kanskje enda mer hygge etterpå. Og så fikk noen den dårlige ideen at det kunne bli en bok. Men det er altså ingen bok i vår tradisjonelle forståelse av tekst som lager en helhet.

\section{Et bedre alternativ}

Siden jeg så sterkt fraråder denne boken, vil jeg gjerne forsøke å gjøre godt igjen med en anbefaling av hvordan det kan gjøres. Den fremtredende amerikanske psykiateren og psykoanalytikeren Glen O. Gabbard - som for øvrig er sønn av to Hollywood-skuespillere og far til en ung skuespillerinne, som innførte en egen filmspalte i sin redaktørperiode i The International Journal of Psychoanalysis, som har skrevet boken The psychology of the Sopranos (4), og som har vært i Oslo og holdt seminarer om TV-seriene Sopranos og In treatmenthar sammen med sin bror litteraturprofessoren publisert Psychiatry and the cinema (5). Den forteller om hvordan psykiater- og psykoterapeutprofesjonen er blitt tematisert gjennom hele den amerikanske filmhistorien. Boken er forbilledlig nettopp fordi den tar idéhistorien på alvor, hvordan forskjellige syn på profesjonen farges av de forskjellige kulturelle klimaene gjennom det forrige århundret. Gabbard utvider vår forståelse av oss selv og de rammene vi arbeider innenfor.

\section{Finn Skårderud}

Avdeling for helse- og sosialfag

Høgskolen i Lillehammer 